Doi: HTTPS://DOI.ORG/10.23910/2/2020.0380

\title{
Bioefficacy of Plant Extracts on Collar Rot Disease (Sclerotium rolfsii Sacc.) of Soybean
}

\author{
Munmi Borah* and Sukanya Gogoi
}

ICAR-All India Coordinated Research Project on Soybean, Jorhat center, Department of Plant Pathology, Assam Agricultural University, Jorhat, Assam (785 013), India

\section{Corresponding Author}

Munmi Borah

e-mail: mborah56@gmail.com

\author{
Article History \\ Article ID: IJEP0380 \\ Received in $29^{\text {th }}$ August, 2020 \\ Received in revised form $15^{\text {th }}$ October, 2020 \\ Accepted in final form $20^{\text {th }}$ November, 2020
}

\section{Abstract}

Among different production constraints in soybean cultivation, the most serious being is diseases. In Assam and other North Eastern states, collar rot caused by Sclerotium rolfsii Sacc. has been found to be a major disease causing plant death and low productivity as rainfall has played a significant role in the establishment of progression of collar rot in soybean. Therefore, the study was undertaken to evaluate the bioefficacy of some commonly available plant extracts against Sclerotium rolfsii Sacc. The aqueous plant extracts of commonly available six plant species were evaluated in vitro by poisoned food technique against their inhibitory effect on the mycelial growth of Sclerotium rolfsii Sacc. Allium sativum was found to be most effective with growth inhibition of $89.77 \%$ followed by Chromolaena odorata ( $86.00 \%$ ), Allamanda cathertica (83.66\%), Laurus nobilis (72.11\%), Ageratum conyzoides (54.88\%) and Aegle marmelos $(50.66 \%)$.

Keywords: Allium sativum, plant extract, Sclerotium rolfsii

\section{Introduction}

Soybean (Glycine max) is most important source of vegetable oil in India that occupies 35-65\% of total oilseed crop in the country. It is known as world's most important crop due to its high protein (35-45\%) and oil content (15-25\%). Due to high protein content, soybean is known as "poor man's meat". Seeds of soybean also contain about $33 \%$ carbohydrates, up to $16.6 \%$ of which are soluble sugars (Hou et al., 2009). Among the grain legumes, it has the greatest potential of producing the cheapest source of food protein (Rao and Reddy, 2010). Frequent soybean protein consumption lowers the cholesterol levels and also reduces the risk of coronary heart disease (FDA, 1999; Henkel, 2000). Moreover, it improves the glucose tolerance in some diabetic patients (Messina, 1999).

The crop is known to be attacked by many fungal, bacterial and viral pathogens causing substantial yield loss. Among the soilborne fungal diseases, collar rot disease of soybean caused by Sclerotium rolfsii Sacc. is a potential threat to soybean production and is of considerable economic significance. The sclerotia produced by this pathogen remains in soil year after year (Chet and Henis, 1972; Punja, 1985). This disease is often found in soybean plants both dry land, rainfed and tidal with attack intensity of 5-55\% (Marlina et al., 2020). S. rolfsii Sacc. attack on soybean plants causes damage to roots, stems, leaves and fruits.
Various ways have been carried out to control collar rot disease in soybean. Use of synthetic pesticides is most common. But synthetic pesticides imbalances our ecology, interferes our food chain and causes many abnormalities to the environment as it usually takes a long time to degrade completely (Damalas and Eleftherohorinos, 2011). Therefore, plant based pesticides appear to be one of the better alternatives for the control of plant diseases, as they are known to have minimal environmental problems and less danger to consumers in contrast to synthetic pesticides (Varma and Dubey, 1999). Plant extracts of many higher plants have been reported to exhibit antibacterial, antifungal and insecticidal properties (Bhatnagar et al. 1990; Tewari, 1995; Fawzi et al., 2009). These botanical pesticides are important because they reduce crop losses; they are eco-friendly, bio-degradable and are cheap and affordable. Several researchers have shown that extracts of many plants may control different fungal plants pathogens. Some also have reported various plant extracts to have antimicrobial activity against S. rolfsii Sacc. infecting different crops, with positive outcomes (Jabbar Sab et al., 2014; Sacchi Sneha et al., 2016; Wavare et al., 2017).

Therefore, the present study has been done to explore the antimicrobial activities of different plant extracts against Sclerotium rolfsii Sacc. causing collar rot disease of soybean under laboratory condition. 


\section{Materials and Methods}

\subsection{Source of fungal pathogen, Sclerotium rolfsii Sacc}

Soybean plants showing typical symptoms of collar rot were collected from the ICAR farm of Assam Agricultural University, Jorhat, Assam (India) (Latitute-26 ${ }^{\circ} 45^{\prime} \mathrm{N}$, Longitue-94 ${ }^{\circ} 12^{\prime}$ $\mathrm{E}$, Altitude- $87 \mathrm{~m}$ with an elevation of $116 \mathrm{~m}$ above mean sea level) and isolation of the pathogen was done after ascertaining their presence in the infected stem under the microscope. Sclerotium rolfsii Sacc. infection occurs at or just below the soil surface. Yellowing or wilting of plants is the first symptom. Leaves turn brown, dry and often cling to dead stem. Numerous tan to brown spherical sclerotia form on infected plant material (Figure 1, A-B) (Borah, 2019; Borah and Saikia, 2019; Belkar et al., 2013; Deb and Dutta, 1991). Thus, identification of the fungal pathogen was done and the pure culture of the fungus was maintained (Figure 1, C-D).
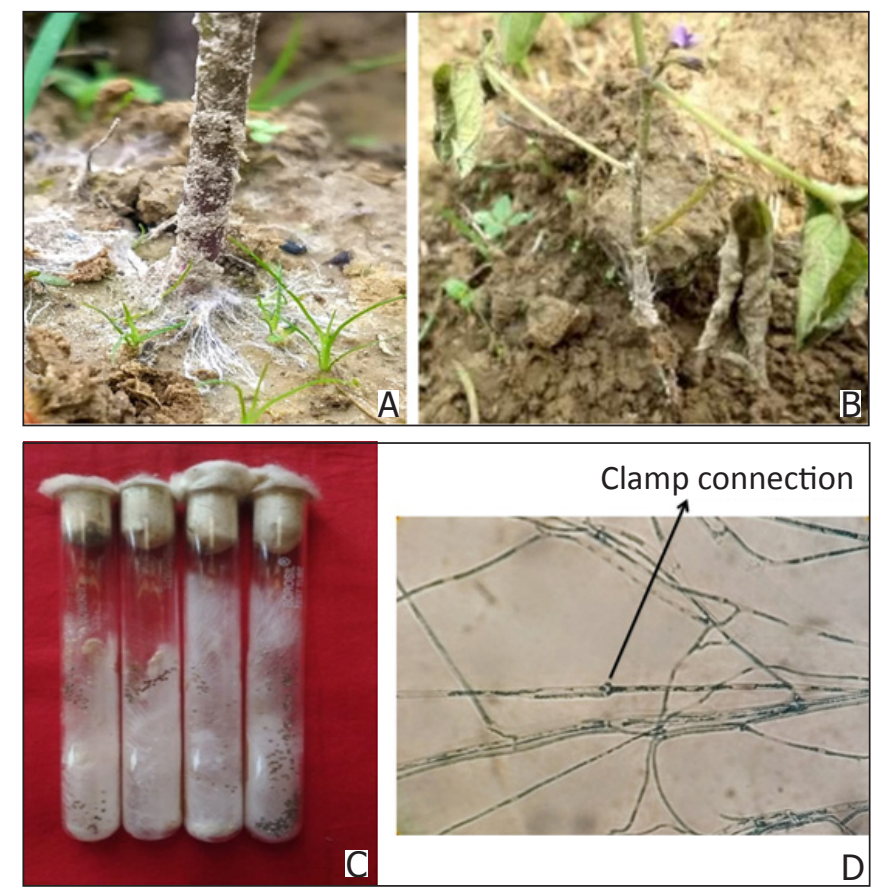

Figure 1: (A), (B) Infection of Sclerotium rolfsii Sacc. causing collar rot disease of soybean in Assam; (C) Isolation and pure culture of the fungus Sclerotium rolfsii Sacc. from the infected plants; (D) Microscopic observation of Sclerotium rolfsii Sacc. isolate showing mycelium of the fungus

\subsection{Collection of botanicals}

Different plant parts (fresh leaves, stem and bulbs) of six selected botanicals were collected from various localities of Jorhat, Assam (Latitute-26 ${ }^{\circ} 45^{\prime} \mathrm{N}$, Longitue-94 $12^{\prime} \mathrm{E}$, Altitude-87m with an elevation of $116 \mathrm{~m}$ above mean sea level) for the preparation of aqueous plant extracts. Different botanicals used in the investigation against Sclerotium rolfsii Sacc. Were Aegle marmelos (leaves), Ageratum conyzoides (leaves and stem), Allamanda cathertica (leaves), Allium sativum (bulb), Chromolaena odorata (leaves) and Laurus nobilis (leaves).

\subsection{Preparation of aqueous plant extracts}

Fresh leaves and other parts of healthy plants were collected and washed thoroughly in sterile distilled water. Hundred grams of washed plant parts was ground in pre-chilled mortar and pestle by adding equal amount $(100 \mathrm{ml})$ of sterilized distilled water $(1: 1 \mathrm{w} / \mathrm{v})$. After grinding, the extract was filtered through muslin cloth and finally the extracts were centrifuged at 10,000 rpm for 20 minutes in centrifuge (Remi C 24) at room temperature. The supernatant was taken as standard plant extract solution (100\%). The method reported by Shekhawat and Prasad (1971) was followed with certain modifications. The plant extracts were further filtered through bacterial membrane filter (RanDisc, PVDF $0.22 \mu \mathrm{m}$ ) under aseptic condition and evaluated at $20 \%$ concentration (for preliminary screening) against the fungus by 'poisoned food technique' (Nene and Thapliyal, 2000).

2.4. Screening of different plant extracts in vitro against $S$. rolfsii Sacc.

The selected fifteen botanicals were screened for their antifungal activity against the pathogen at $20 \%$ concentration. For this, PDA medium was prepared in $250 \mathrm{ml}$ Erlenmeyer flasks and sterilized. $20 \mathrm{ml}$ of $100 \%$ aqueous plant extracts of each botanicals were aseptically added to $80 \mathrm{ml}$ PDA in flasks so as to get the final concentration of $20 \%$ of the extracts in the medium. PDA without any extract served as control. The media was poured in $9 \mathrm{~cm}$ Petri plates at the rate of $20 \mathrm{ml} /$ plate. The fungal culture disc using a cork borer $(5 \mathrm{~mm}$ diameter) from the tip, obtained from a 7 days old culture were taken and inoculated in the centre of petri plates aseptically after solidification of the medium and incubated at $28 \pm 1$ 으 for 7 days. The diameter of the colony is measured when the mycelium fully covered the control plates and the inhibition of the mycelial growth of the other treatments were calculated by the formula given by Vincent (1927):

$\mathrm{I}=(\mathrm{C}-\mathrm{T}) / \mathrm{C} \times 100$

Where, I = Inhibition of mycelial growth,

$\mathrm{C}=$ Growth in control,

$\mathrm{T}=$ Growth in treatment

\section{Results and Discussion}

The results revealed in Table 1 showed that all the plant extracts significantly inhibited the growth of the Sclerotium rolfsii.

Amongst all the six botanicals tested, maximum inhibition on mycelial growth of $S$. rolfsii was found in Allium sativum (89.77\%) followed by extracts of Chromolaena odorata (86.00\%), Allamanda cathertica (83.66\%), Laurus nobilis (72.11\%), Ageratum conyzoides (54.88\%) and the least was shown by Aegle marmelos (50.66\%). The results of the present investigation are analogous to the previous findings published by several workers. 
Table 1: In vitro Efficacy of bioproducts on collar rot disease (Sclerotium rolfsii) of soybean

\begin{tabular}{llcc}
\hline $\begin{array}{l}\text { SI. } \\
\text { No. }\end{array}$ & $\begin{array}{c}\text { Mycelial } \\
\text { growth }^{*}(\mathrm{~cm})\end{array}$ & $\begin{array}{c}\text { Inhibition over } \\
\text { control (\%) }\end{array}$ \\
\hline 1. & Aegle marmelos & 4.44 & 50.66 \\
2. & $\begin{array}{l}\text { Ageratum } \\
\text { conyzoides }\end{array}$ & 4.06 & 54.88 \\
3. $\quad \begin{array}{l}\text { Allamanda } \\
\text { cathertica }\end{array}$ & 1.47 & 83.66 \\
4. Allium sativum & 0.92 & 89.77 \\
5. Chromolaena & 1.26 & 86.00 \\
& odorata & & \\
6. Lauris nobilis & 2.51 & 72.11 \\
7. Control & 9.00 & - \\
& SEd & 0.080 & - \\
& CD ( $p=0.05)$ & 0.168 & - \\
\hline
\end{tabular}

${ }^{*}$ After 7 days of incubation at $28 \pm 1^{\circ} \mathrm{C}$, Mean of five replications

Karade and Sawant (1999) tested extracts of 12 medicinal plants against Alternaria alternate and observed $100 \%$ inhibition of spore germination by Allium sativum extract. Again, Kshirsagar et al. (2004) found that the crude extracts of garlic completely inhibited (100\%) the mycelial growth of Rhizoctonia solani causing root rot of cotton. Of all the Allium species, garlic is the most important because of the presence of sulfur compounds like Allicin (diallyl-dithiosulfinate), diallyl disulphide (DADS), S-allylcysteine (SAC), diallyl trisulfide (DATS) etc. Durbin and Uchytil (1971) also reported that $A$. sativum extract contains allicin (antibiotic in nature) which can be used for the control of pathogenic bacteria and fungi.

The aqueous extracts of Chromolaena odorata was also used to control Onion bulb rot caused by Aspergillus niger at 75 g $100 \mathrm{ml}^{-1}$ concentration. Allelopathic effect of leaf extract of Chromolaena odorata was reported by Yeni et al. (2010) against post-harvest and transit rot of tomato. Adeyemi et al. (2018) found that the minimum inhibitory concentration showed that $50 \mathrm{mg} \mathrm{ml}^{-1}$ and $25 \mathrm{mg} \mathrm{ml}^{-1}$ of cold water extract of C. odorata had fungicidal effect against Phytophthora megakarya. The inhibitory effect of the plant might be due to the presence of steroids, terpenoids, alkaloids, flavonoids, glucosinulate, amino acid, tannins, phenolic compounds and saponins.

Allamanda extract was found to be inhibitory against many disease causing plant pathogens like Phomopsis vexans, Phytophthora capsici, Fusarium oxysporum, Rhizoctonia solani (Panda et al., 1996; Khan, 1999; Jannat, 2006; Tania, 2007). Islam (2004) found $76-100 \%$ inhibition of mycelial growth of Phomopsis vexans by Garlic bulbs and Allamanda leaf extracts. Several researchers in India isolated and reported some antimicrobial compounds from Allamanda, like plumericin, isoplumericin, plumieride, long chain esters, etc. (Manogaran and Sulochana, 2005; Tiwari et al., 2002).

Fawzi et al. (2009) tested five plant extracts against pathogenic fungi Alternaria alternata and Fusarium oxysporum in vitro and found that Lauris nobilis can be successfully used for antifungal control. Bajwa et al. (2001) reported that the growth of Aspergillus fumigatus was significantly checked by aqueous root and shoot extracts of Ageratum conyzoides. Javed and Bashir (2012) also found that the aqueous and organic solvent extracts of $A$. conyzoides greatly reduced the biomass of Fusarium solani. Crude or refined extracts from $A$. conyzoides offer the possibility of biocontrol of plant pathogenic fungi (Iqbal et al., 2004). According to Tran et al. (2004), three phenolic compounds were identified in the leaf, stem and root of $A$. conyzoides including gallic acid, coumallic acid and protocatechuic acid and catechin was found only in the stem.

Zade et al. (2005) reported that the effectiveness of leaf extracts of Aegle marmelos at 50 and $100 \%$ concentrations in inhibiting the growth of uredospore germination of Puccinia arachidis in groundnut. The essential oil from the leaves of $A$. marmelos is known to exhibited antifungal properties (Renu et al., 1986; Rana et al., 1997).

\section{Conclusion}

In the present investigation, amongst all the six botanicals tested, Allium sativum, Chromolaena odorata, Allamanda cathertica and Laurus nobilis showed higher inhibition on mycelial growth of the fungus causing collar rot disease of soybean. All the four botanicals have strong toxic principles present in their extract which directly inhibit the growth of the fungus, as well as act as an outstandingly good model of biological control agent. These botanicals can be used as a possible substitute for synthetic fungicides.

\section{References}

Adeyemi, A., Vincent, O., Olujenyo, O., 2018. Phytochemical screening and antifungal activity of Chromolaena odorata extracts against isolate of Phytophthora megakarya using agar-well diffusion method. Asian Journal of Medical and Biological Research 4, 7-13.

Bajwa, R., Akhtar, N., Javaid, A., 2001. Antifungal activity of allelopathic plant extracts. I. Effect of aqueous extracts of three allelopathic Asteraceous species on growth of Aspergilla. Pakistan Journal of Biological Sciences 4, 503-507.

Belkar, Y., Gade, R., Panjabrao, D., 2013. Management of root rot and collar rot of soybean by antagonistic microorganism. Journal of Plant Disease Sciences 8, 39-42.

Bhatnagar, D., Zeringue, H.J., Cormick, S.P., 1990. Neem leaf extracts inhibit aflatoxin biosynthesis in Aspergillus flavus and A. parasiticus. In Proceedings of the USDA 
neem workshop, 118-127.

Borah, M., Saikia, H., 2019. Influence of weather parameters on the development of collar rot of soybean caused by Sclerotium rolfsii. International Journal of Current Microbiology and Applied Sciences 8, 1667-1675.

Borah, M., 2019. Identification of soybean diseases in assam. International Journal of Recent Science and Research 10, 34154-34159.

Chet, I., Henis, Y., 1972. The response of two type of Sclerotium rolfsii to factors affecting Sclerotium formation. Journal of General Microbiology 73, 483-486.

Damalas, C.A., Eleftherohorinos, I.G. 2011. Pesticide exposure, safety issues, and risk assessment indicators. International Journal of Environmental Research and Public Health 8, 1402-1419.

Deb, P.R., Dutta, B.K., 1991. Studies on biological control of foot rot disease of soybean caused by Sclerotium rolfsii Sacc. Journal of Plant Diseases and Protection 98, 539-546.

Durbin, R.D., Uchytil, T.F., 1971. The role of allicin in the resistance of garlic to Penicillium spp. Phytopathologia Mediterranea 10, 227-230.

Fawzi, E.M., Khalil, A.A., Afifi, A.F., 2009. Antifungal effect of some plant extracts on Alternaria alternate and Fusarium oxysporum. African Journal of Biotechnology 8, 2590-2597.

Food and Drug Administration (FDA), 1999. FDA approves new health claim for soybean protein and coronary heart disease. FDA Talk Paper, in www.fda.gov.G. (ed.) The Soybean: Botany, Production and Uses.

Henkel, J., 2000. Soybean: Health claims for soybean protein, questions about other components. FDA Consumer, in www.cfsan.fda.gov.

Hou, A., Chen, P., Alloatti, J., Mozzoni, L., Zhang, B., Shi, A., 2009. Genetic variability of seed sugar content in worldwide soybean germplasm collections. Crop Science 49, 903-912.

Iqbal, M.C.M., Jayasinghe, U.L.B., Herath, H.M.T.B., Wijesekara, K.B., Fujimoto, Y. 2004. A fungistatic chromene from Ageratum conyzoides. Phytopathology 32, 119-126.

Islam, R., 2004. Chromatographic separation of components in garlic bulb and Allamanda leaf extracts inhibitory to Phomopsis vexans [MS thesis]. Mymensingh: Department of Plant Pathology, Bangladesh Agricultural University, 35.

Jabbar, S., Nagaraja, A., Nagamma, G., 2014. Efficacy of bio-pesticides against Sclerotium rolfsii Sacc. causing collar rot of chickpea (Cicer arietinum I.). The Bioscan 9, 335-339.

Jannat, R., 2006. Determination of functional groups and molecular structure of the compounds in Allamanda leaf extracts inhibitory to Phomopsis vexans [MS thesis]. Mymensingh: Department of Plant Pathology, Bangladesh Agricultural University, 74-76.

Javed, Uzma, B., 2012. Antifungal activity of different extracts of Ageratum conyzoides for the management of Fusarium solani. African Journal of Biotechnology 11, 11022-11029.

Karade, V.M., Sawant, D.M., 1999. Effect of some plant extracts on the spore germination of Alternaria alternata. Plant Disease Research 14, 75-77.

Khan, N.U., 1999. Studies on epidemiology, seed borne nature and management of Phomopsis fruit rot of Brinjal [MS thesis]. Mymensingh: Department of Plant Pathology, Bangladesh Agricultural University, 38-68.

Kshirsagar, C.R., Jadhav, A.C.,Nimbalkar, R.D., 2004. In vitro evaluation of plant extracts against Rhizoctonia solani causing root rot of cotton. Journal of Cotton Research and Development 18, 202-203.

Manogaran, S., Sulochana, N., 2005. Extraction and characterization of Allamanda cathartica. Asian Journal of Chemistry 17, 1955-1958.

Marlina, L.H., Alfizar, S., 2020. Sclerotium rolfsii Sacc. Control, causes of collar rot disease in soybeans with mycorrhizal biological agents. Systematic Reviews in Pharmacy 11, 289-291.

Messina, M.J., 1999. Legumes and soybeans: overview of their nutritional profiles and health effects. American Journal of Clinical Nutrition 70, 439-450.

Nene, Y.L., Thapliyal, P.N., 2000. Fungicides in Plant Disease Control. (5 $5^{\text {th }}$ Ed.) Oxford and IBH publishing Co. Pvt. Ltd., New Delhi, 325.

Panda, R.N., Tripathy, S.K., Kar, J., Mohanty, A.K., 1996. Antifungal efficacy of homeopathic drugs and leaf extracts in Brinjal. Environment and Ecology 14, 292-294.

Punja, Z.K., 1985. The biology, ecology and control of Sclerotium rolfsii. Annual Reviews in Phytopatholog 23, 97-127.

Rana, B.K., Singh, U.P., Taneja, V., 1997. Antifungal activity and kinetics of inhibition by essential oil isolated from leaves of Aegle marmelos. Journal of Ethnopharmacology 57, 29-34.

Rao, A.S., Reddy, K.S., 2010. Nutrient management in soybean. In: Singh, G. (Ed.), The soybean: Botany, production and uses. CAB International, 30.

Renu, H.V.M., Dubey, N.K., Dixit, S.N., 1986. Mycotoxic properties of the essential oil of Aegle marmelos. Beit. Biol. Pflanz 60, 325-332.

Sacchi, S., Maurya, S., Choudhary, A.K., 2016. Antifungal efficacy of aqueous extracts of some spices against Sclerotium rolfsii. The Bioscan 11, 1537-1540.

Shekhawat, P.S., Prasada, R., 1971. Antifungal properties of some plant extracts: Inhibition of spore germination. Indian Phytopathology 24, 800-802.

Tania, F.I., 2007. Investigation of structural characteristics of Allamanda leaf extract components inhibiting the growth of some important plant pathology [MS thesis]. Mymensingh: Department of Plant Pathology, Bangladesh Agricultural University, 1-80. 
Tewari, S.N., 1995. Ocimum sanctum L., a botanical fungicide for rice blast control. Tropical Science 35, 263-273.

Tiwari, T.N., Pandey, V.B., Dubey, N.K., 2002. Plumieride from Allamanda cathartica as an antidermatophytic agent. Department of Botany, Banaras Hindu University, Varansi, India. Phytotherapy Research 16, 393-394.

Tran, D.X., Shinkichi, T., Hong, N.H., Khanh, T.D., Min, C.I., 2004. Assessment of phytotoxic action of Ageratum conyzoides L. (billy goat weed) on weeds. Crop Protection 23, 915-922.

Varma, J., Dubey, N.K., 1999. Prospectives of botanical and microbial products as pesticides of Tomorrow. Current Science 76, 172-179.

Vincent, J.M., 1927. Distortion of fungal hyphae in the presence of certain inhibitors. Nature 59, 850.
Wavare, S.H., Gade, R.M., Shitole, A.V., 2017. Effect of plant extracts, bio agents and fungicides against Sclerotium rolfsii causing collar rot in chickpea. Indian Journal of Pharmaceutical Sciences 79, 513-520.

Yeni, I.J., Dele, O.S., Ademola, I.J., Adeniran, A.J., Plantation, M., 2010. Allelopathic effect of leaf extract of Azardirachta indica and Chromolaena odorata against post harvest and transit rot of tomato (Lycopersicum esculentum $\mathrm{L}$ ). Biology, Corpus ID 53504316.

Zade, S.R., Buldeo, A.N., Lanje, P.W., Gulhane, V.G., 2005. Evaluation of plant extracts and culture filtrates of bioagents against Puccinia arachidis Speg. in groundnut. Journal of Soils and Crops 15, 150-154. 